\title{
THE EVALUATION OF THE IMPACT OF SOCIAL CAPITAL ON ECONOMIC DEVELOPMENT WITHIN THE FRAMEWORK OF THE LEGATUM PROSPERITY INDEX: THE CASE OF OECD COUNTRIES
}

\author{
SOSYAL SERMAYENIN EKONOMIK KALKINMA ÜZERINDEKİ ETKİSININ LEGATUM \\ REFAH ENDEKSİ ÇERÇEVESINDE DEĞERLENDİRILMESİ: OECD ÜLKELERİ ÖRNEĞİ
}

\author{
Eylül KABAKÇI GÜNAY ${ }^{1}$ - Dilara SÜLÜN ${ }^{2}$
}

\begin{abstract}
Social capital is one of the variables that influences overcoming problems related to welfare and development. Studies show that social capital level is generally in a linear relationship with the development level of countries. The purpose of study is to examine the relationship between the welfare levels of OECD countries and their social capital levels within the framework of the Legatum Prosperity Index. For this, the effect of social capital, which is one of the 12 components of the Legatum Prosperity index, on the welfare level of OECD countries was examined. the country rankings in which social capital is equally weighted with other index variables and the country rankings where social capital is excluded from the index are compared. The results obtained show that social capital is improving for the rankings of the welfare levels of Norway, Denmark, Iceland, New Zealand, Canada, Australia, USA, Slovenia, Portugal, Israel, Slovakia; has deteriorating effect for Switzerland, United Kingdom, Luxembourg, France, Belgium, Hungary, Czech Republic, Greece, Mexico, Latvia, Japan, Lithuania, South Korea and Turkey. Social capital variable alone did not make a difference in the welfare level rankings of Finland, Netherlands, Sweden, Austria, Ireland, Germany, Spain, Estonia, Italy, Chile, Colombia and Poland.
\end{abstract}

Keywords: Social Capital, OECD, Economic Development, Legatum Prosperity Index

\section{$\ddot{O} \mathbf{z}$}

Sosyal sermaye, refah ve kalkınmayla ilgili sorunların giderilmesinde etkisi olan değişkenlerden biridir. Araştırmalar, sosyal sermaye düzeyinin ülkelerin kalkınmışlık düzeyi ile genellikle doğrusal bir ilişki içerisinde olduğunu göstermektedir. Bu çalışmanın amacı, OECD ülkelerinin refah düzeyleri ile sosyal sermaye düzeyleri arasındaki ilişkinin Legatum Refah Endeksi çerçevesinde incelenmesidir. Bunun için Legatum Refah Endeksi'nin 12 bileşeninden biri olan sosyal sermayenin OECD ülkelerinin refah seviyesine etkisi incelenmiştir. Bu amaçla sosyal sermayenin diğer endeks değişkenleri ile eşit ağırlıkta yer aldığı durumdaki ülke sıralamaları ile sosyal sermayenin endeksten çıkartıldığı durumdaki ülke sıralamaları karşılaştırılmıştır. Karşılaştırma neticesinde, ülkelerin endeksteki yeni yerlerinin eskisine göre durumları ve aradaki fark irdelenmiştir. Elde edilen sonuçlar göstermiştir ki sosyal sermayenin Norveç, Danimarka, İzlanda, Yeni Zelanda, Kanada, Avustralya, ABD, Slovenya, Portekiz, Israil, Slovakya'nın refah seviyeleri sıralamaları için iyileştirici; İsviçre, İngiltere, Lüksemburg, Fransa, Belçika, Macaristan, Çekya, Yunanistan, Meksika, Letonya, Japonya, Litvanya, Güney Kore ve Türkiye'nin refah seviyesi sıralamaları için kötüleştirici etkisi vardır. Finlandiya, Hollanda, İsveç, Avusturya, İrlanda, Almanya, İspanya, Estonya, İtalya, Şili, Kolombiya ve Polonya'nın refah seviyesi sıralamalarında ise sosyal sermaye değişkeni tek başına farklılık yaratmamıştır.

Anahtar Kelimeler: Sosyal Sermaye, OECD, Ekonomik Kalkınma, Legatum Refah Endeksi

\footnotetext{
${ }^{1}$ Assist. Prof. Dr., İzmir Demokrasi University, Faculty of Economics and Administrative Sciences, eylul.kabakci@idu.edu.tr, Orcid:0000-0001-5547-4316

2 Assist. Prof. Dr., İzmir Demokrasi University, Faculty of Economics and Administrative Sciences, dilara.sulun@idu.edu.tr, Orcid:0000-0001-8874-5194
} 


\section{INTRODUCTION}

Economic growth is a very crucial concept for economic development and welfare. As it is known, economic growth means an increase in the production capacity of a country in years. But the existence of economic growth does not necessarily indicate the existence of development, but we can say that economic growth occurs in a developed country. In this respect, economic development and prosperity which would be achieved in result of economic development are multi-dimensional concepts. For a country to develop, education, health and security services should be provided at the desired level, freedom and equality between genders should be ensured. The high production power of the economy does not mean that the welfare level is high. Because high economic growth rate alone is not sufficient for economic development. If economic development is a watch, one of the gears required for this watch to work properly is economic growth. However, gears need to be oiled from time to time to function perfectly. This oil is social capital indeed.

The first known use of the term "social capital" belongs to Lyda Judson Hanifan. American reformist, educator Hanifan, in his work named "The Rural School Community Center" in 1916, found goodwill, friendship, sympathy and social understanding among individuals and families who are outside the economic dimension of capital, but who contribute to it, who form social integrity. He developed the concept of social capital to draw attention to the existence of certain relationships (Şan and Şimşek, 2011: 93).

Social capital is briefly understood as a concept that emphasizes the importance of relationships and enables individuals to easily overcome situations that they cannot or will take time to achieve alone, thanks to keeping relationships strong. It is possible for individuals to do tasks that will take time to overcome while alone, with the help of another person, to increase their sense of satisfaction, and to the richness of the network of relationships between people. These networks are referred to as a kind of capital, as this can ultimately enable the planned work to be done more efficiently. Thus, as individuals establish good relationships with each other and nurture these relationships towards achieving goals, these abstract and invisible networks of relationships between them can become visible. Social capital is thus named as an economic term through this feature. Inter-personal trust, family bonds and friend relations contribute to the better achievement of personal well-being. Research show that there is a positive correlation between low levels of trust and low levels of economic performance. Thus, the term of "capital" in "social capital" reflects the positive economic added value of social networks. For such reasons, the relationship between social capital and welfare level should be examined. In addition, the differences in the economic development of countries with stronger social capital should be revealed.

\section{CONCEPTUAL FRAMEWORK}

\subsection{Concept and Definition of the Social Capital}

Social capital explains the close relationships and harmony that countries experience when there is trust between people. Social capital in a broader sense refers to factors such as interpersonal relationships, social groups that function effectively, encompassing a common awareness of identity, trust, and norms cooperation, but a clear definition has not been reached yet. Social capital can reflect a social network which acts as a facilitator in reaching the targets. Thus, we can say that social capital can be considered as informal rules and common values allowing a collaboration between persons. In other words, social capital is the sum of interpersonal and social networks.

Studies conducted with social capital over time have shown that the concept is multidimensional. Social capital has economic, social, and political aspects. The growing interest 
in social capital is partly due to concrete results of networks and mutual assistance that contribute that improves the performance of governance accompanied with better success and achievement in economic and social terms as well as in personal development. There are four important name who have carried remarkable studies in social capital. These are Pierre Bourdieu, James Coleman, Robert D. Putnam and Francis Fukuyama.

According to Pierre Bourdieu, it is the capital of social relations that provides useful support when necessary. It is the capital of respectability and dignity that is often indispensable for those who have positions that are also of monetary value, such as a political career, when anyone reaches socially important positions. In addition, according to Pierre Bourdieu, social capital is the sum of real and potential resources dependent on having long-term communication networks. In this context, social capital can be defined as the basic elements necessary for individuals to mobilize their economic and cultural capital (Bourdieu, 1986: 49).

According to James Coleman, social capital is a set of resources that exist in family ties and social institutions of society and are beneficial to the social and cognitive development of a child or young person. These resources differ for different people, and they are an important advantage for the human capital development of children and young people. Again, according to Coleman, social capital is not only a concept created and benefited by those who realize it, it also becomes an excellent public property that can be used by all parts of the structure (Coleman, 1998).

According to Robert D. Putnam, social capital is the characteristics of social life such as communication networks, norms and trust that enable participants to act together to maintain shared objects. Here, social capital refers to the characteristics of social organizations such as trust, norms, communication networks that facilitate the effectiveness of society through coordinated actions. Putnam's studies are also important in examining what subcomponents of social capital are. Putnam, in his study entitled "Making Democracy Work: Civic Traditions in Modern Italy", investigated the reasons for the higher economic success of local governments in the north of Italy compared to the local governments in the south Italy and the reasons for the differences between these two regions. The results of his research showed that non-governmental organizations in Northern Italy are much more effective than local governments in Southern Italy. According to Putnam, civic activities of citizens in regions with a well-functioning local government and economic prosperity have created an environment where cooperation, vital social networks, equal political relations, and political participation are widespread (Putnam, 1994: 6).

In 1995, social scientist Francis Fukuyama published the remarkable work "Trust, the Social Virtues and the Creation of Prosperity". According to Fukuyama, individualism threatens American society. Italy and China, on the other hand, are threatened by the close family ties on which the social structure is based, as well as strong government control. Besides, according to Fukuyama, Japan and Germany, have the social capital which is necessary to build large-scale organizations in modern production and which strengthens loyalty (Fukuyama, 1995).

As can be understood from the definitions given so far, the social capital of a nation is the sum of social stability and the welfare (perceived or real) of the whole population. Social capital creates social cohesion and a certain level of consensus, which provides a stable environment for the economy and prevents excessive exploitation of natural resources. However, it should not be forgotten that there may be countries where social capital does not always have a positive effect. Although the concept of social capital usually has a positive meaning for its users, it is noticed that it can also have bad effects by strengthening some negative situations, which is referred to as the "dark side" of social capital to explain this situation (Field, 2008: 101). 


\subsection{Concept and Definition of the Welfare and Legatum Prosperity Index}

As it is known, 'welfare' is the main output obtained because of 'development'. For countries where crucial to increase their welfare, development represents a way through. Considered in this context, 'economic growth' is necessary for 'development', but it is not enough alone. The existence of economic growth does not indicate the existence of development, but we can say that economic growth occurs in a developed country. In this respect, economic development and prosperity which would be achieved in result of economic development are multi-dimensional concepts. For example; a country that wants to develop education, health and security services at the desired level, freedom and equality between genders should be ensured. Because economic growth is not the ultimate recipe for building a developed society, but a component. But other components like equality in genders, high quality education, better health service, democracy and freedom are essentials for a developed country.

There are some indices which measure wellbeing and prosperity like Better Life Index, Happy Planet Index, Human Development Index. One of them is Legatum Prosperity Index. The Legatum Prosperity Index is an annual welfare ranking within 167 countries, covering $96 \%$ of the world's population and 99\% of global gross domestic product (GDP). Legatum Prosperity Index also is known as "Global Prosperity Index" and it explains the necessary conditions for well-being. There are twelve pillars used in establishing the Legatum Prosperity index. These are "safety and security, personal freedom, governance, social capital, investment environment, entrepreneurial conditions, market access and infrastructure, economic quality, living conditions, health, education, and natural environment". It is concluded that the Legatum Prosperity Index can be considered as a valid source of welfare assessment as it expresses dimensions that are fundamental to individual or national well-being. The Legatum Prosperity Index allows to reduce the dependence on GDP measures, which are frequently used in welfare comparisons of countries (Khan and Ahmad, 2019: 425).

Table 1. Legatum Prosperity Index Pillars and Definitions

\begin{tabular}{|l|l|}
\hline PILLARS & DEFINITIONS \\
\hline Safety \& Security & $\begin{array}{l}\text { "measures the degree to which war, conflict, terror, and crime } \\
\text { have destabilised the security of individuals, both immediately } \\
\text { and through longer lasting effects" }\end{array}$ \\
\hline Personal Freedom & $\begin{array}{l}\text { "measures progress towards basic legal rights, individual } \\
\text { liberties, and social tolerance." }\end{array}$ \\
\hline Governance & $\begin{array}{l}\text { "measures the extent to which there are checks and restraints } \\
\text { on power and whether governments operate effectively and } \\
\text { without corruption." }\end{array}$ \\
\hline Social Capital & $\begin{array}{l}\text { "measures the strength of personal and social relationships, } \\
\text { institutional trust, social norms and civic participation in a } \\
\text { country." }\end{array}$ \\
\hline The Enterprise Conditions & $\begin{array}{l}\text { "measures the extent to which investments are adequately } \\
\text { protected and are readily accessible" }\end{array}$ \\
\hline "measures the degree to which regulations enable businesses \\
to start, compete, and expand."
\end{tabular}




\begin{tabular}{|l|l|}
\hline Living Condition & $\begin{array}{l}\text { "measures the degree to which a reasonable quality of life is } \\
\text { experienced by all, including material resources, shelter, basic } \\
\text { services, and connectivity." }\end{array}$ \\
\hline Health & $\begin{array}{l}\text { "measures the extent to which people are healthy and have } \\
\text { access to the necessary services to maintain good health, } \\
\text { including health outcomes, health systems, illness and risk } \\
\text { factors, and mortality rates" }\end{array}$ \\
\hline Education & $\begin{array}{l}\text { "measures enrolment, outcomes, and quality across four stages } \\
\text { of education (pre-primary, primary, secondary, and tertiary } \\
\text { education), as well as the skills in the adult population." }\end{array}$ \\
\hline Natural Environment & $\begin{array}{l}\text { "measures the aspects of the physical environment that have a } \\
\text { direct effect on people in their daily lives and changes that } \\
\text { might impact the prosperity of future generations." }\end{array}$ \\
\hline
\end{tabular}

Source: Legatum Prosperity Index, https://docs.prosperity.com/3916/0568/0669/The_Legatum_Prosperity_Index_2020_Overview.p df Accessed Date: 15.10.2021

According to table 1, the Legatum Prosperity Index, prosperity has 12 components. Social capital, one of these components, measures the strength of individual and social relations, inter-institutional trust, social norms and civic participation. Legatum Prosperity index accepts social capital as a welfare component, revealing a different perspective for welfare measurement. As we mentioned in the study before, social capital is not a concrete value and therefore it is difficult to measure and evaluate in numerical values. The Legatum Prosperity Index considers social capital as a variable affecting the welfare level, it is different from more traditional indices such as human development indices, poverty indices etc. differentiates from more traditional indices.

The social capital used as a component of the Legatum index is calculated on 5 basic factors. Elements of "Social Capital" are "Personal and Family Relationships", "Social Networks", "Interpersonal Trust", "Corporate Trust" and "Citizenship and Social Participation".

1. Personal and Family Relationships: represent the power of strong and close family and individual ties. Indeed, strong family bonds and close friend relations establish the ground for people's mental and financial development.

2. Social Networks: represent people's strength and opportunities with their social and close network. In fact, these relations are essential for social support, and when these social networks and community networks embrace different layers of society, they can support the establishment of a capital bridge, the ease of transferring capital owned by individuals. Forging and enhancing relations with close social network members such as families, neighbors or friends is essential part to form a local social circle.

3. Interpersonal Trust: represents the level of trust in a group or country, which includes how much people trust "others" and "strangers". This variable describes how reliable individuals see each other.

4. Institutional Trust: represents the level of trust of people in their institution.

5. Citizenship and Social Participation: represents the amount of people involved in a society which is generally divided into civic and social spheres. Individuals can feel deep ties to 
their country of citizenship, and they can also add themselves to that social layer by defining the layer they belong to in the society ${ }^{3}$.

\subsection{The Conceptual Framework of the OECD}

The Organization for Economic Co-operation and Development (OECD) is defined as part of the system of western organizations established after the Second World War. The organization was founded after the second World War, with the aim of supporting and repairing the economies of Western Europe, within the framework of the Marshall Plan, to help the distribution of the financial assistance of the USA and Canada, which was around 12 billion US dollars at that time, and upon the completion of the function of the Organization for European Economic Cooperation (OEEC), which was active between 1947 and 1960's to develop trade between European countries by liberalizing trade payments. OECD was established in its place and within a broader mission of tasks. The "Convention on the Organization for Economic Cooperation and Development" signed in Paris on 14 December 1960 constitutes the founding agreement of the OECD.

The OECD member countries in 2020 are Turkey, USA, Germany, Australia, Austria, Belgium, Czechia, Denmark, Estonia, Finland, France, Republic of Korea, the Netherlands, England, Ireland, Spain, Israel, Sweden, Switzerland, Italy, Japan, Iceland, Canada, Colombia, Latvia, Lithuania, Luxembourg, Hungary, Mexico, Norway, Poland, Portugal, Slovakia, Slovenia, Chile, New Zealand and Greece. The main objectives of the OECD are as follows.

- To guide governments in achieving prosperity and fighting poverty through cooperation in economic growth, financial stability, trade and investment, technology, innovation, entrepreneurship, and development,

- Observing the balance between economic and social development and environmental protection,

- Creating job opportunities for all, an effective healthy governance with social equality.

In this respect, it can be said that the primary purpose of OECD countries is to ensure the development of its member countries. The social capital component also emerges as a component that countries need to improve to increase their development levels. The OECD is established indeed within these purposes; thus, we aim in this study to discuss the role of social capital in the welfare levels among the OECD countries.

\section{LITERATURE REVIEW}

The context and extent of the relationship between social capital and economic growth is a question that researchers seek answers to. Because, when the literature is researched, it is difficult to predict at what points social capital, which can be associated with relationships, ties, trust and human capital elements, may have an impact on economic growth. In this regard, it is useful to refer to previous studies. Some of the studies investigate the relationship between these two variables as follows;

According to Knack and Keefer (1997), "social capital" matters for measurable economic performance, using indicators of trust and civic norms from the World Values Surveys for a sample of 29 market economies. They find trust and civic norms are stronger in nations with higher and more equal incomes, with institutions that restrain predatory actions of chief executives, and with better-educated and ethnically ho-mogeneous populations.

\footnotetext{
${ }^{3}$ https://prosperitysite.s3accelerate.amazonaws.com/7515/8634/9002/Methodology_for_Legatum_Prosperity_Index_2019.pdf, Accessed Date: 16.10 .2020
} 
According to Woolcock (1998), social capital is a conceptual tool that can potentially make important contributions to questions of economic development and can be found in some respects, which in some respects complements orthodox economic approaches.

According to Whiteley (2000), the relationship between social capital and economic growth in a sample of thirty-four countries over the period 1970-1992 is statistically significant. The social capital has an impact on growth which is at least as strong as that of human capital or education.

According to Rupasingha, Goetz and Freshwater (2000), the effect of social capital on economic growth is examined using linear regression analysis and U.S. county-level data. Results reveal that social capital has a statistically signif-icant, independent positive effect on the rate of per-capita income growth.

According to Torsvik (2000), social capital is related with trust. In this case, the trust creates diminishing effects on transaction costs. Torsvik indicates social capital has an indirect blooming effect on economic growth.

According to Karagül and Akçay (2002), the relationship between economic growth and social capital suggests that there is a statistically significant positive relationship between economic growth and social capital for the period of 1980-1995 across 36 developed and developing countries for the periods of 1960-1995 and 1980-1995.

According to Sabbatini (2005), relationship is calculated for three main social capital dimensions (i.e. bonding, bridging and linking social capital) and measures them through synthetic indicators built by means of principal component analyses performed on a dataset including multiple variables. Outcomes provide a proof of Putnam's claims on the positive role of civil society organizations in development processes.

According to Soumyananda (2012), the mechanism by which social capital contributes, creates economic growth within the framework of endogenous growth model. So Soumyananda claims in the countries which have deeper social connections indicate to better social capital, the economic growth rate is higher than the traditional growth rate.

Działek (2014), investigates the social capital is useful for explaining economic development in Polish regions or not. The results demonstrate that despite the existing differences between regions there are no significant relationships between levels of social capital and economic development.

Peiro Palomino (2016), analyses the role of two social capital indicators on the growth of 237 European regions in the period 1995-2007 by implementing non-parametric regression in his study. The results show that social capital effects on growth are nonlinear. Parameter heterogeneity could also be examined, showing heterogenous effects across regions and over time. In particular, the social capital is mostly negative in regions from Eastern and Central Europe during the first years of transition from socialism to market economies.

Consequently, the results of studies on whether social capital affects economic growth vary in the context of the country and region. Some studies conclude that social capital affects growth positively, while others do not.

\section{METHODOLOGY}

In this study, social capital, which is one of the components of the welfare level, is compared for OECD countries in the Legatum Prosperity index, and the effect of social capital differences on development between countries is tried to be understood. While doing this, it has been tried to reveal whether there is a welfare and productivity enhancing aspect ascribed to 
social capital in the literature or the "dark" side that is rarely mentioned. Legatum Prosperity Index was used in the study to observe and compare the social capital index values of OECD countries. As mentioned before, Legatum index uses 12 variables to determine the welfare level. These variables are "protection and security, individual freedom, governance, social capital, investment environment, entrepreneurial conditions, market access and infrastructure, economic quality, living conditions, health, education, and natural environment". The welfare index is obtained by weighting these variables. In our study, rankings of OECD countries are used, not the values of the welfare index. Thus, it has been tried to determine whether the countries are in a more advantageous or disadvantageous position compared to each other in terms of welfare level and social capital.

For this, first of all, the ranking of the countries with equal weighting of all components of the index was examined, and then the weighting of the social capital index was equal to zero and the new ranking was reached. These two rankings are compared for OECD countries, and the countries which have the greatest differences are revealed. By doing this, it is aimed to obtain the value of the welfare level when the one of the index components is social capital and the value of the welfare level when the social capital is not an index component. Thus, the effect of social capital on the welfare levels of OECD countries according to the Legatum Prosperity Index is revealed.

\section{FINDINGS AND DISCUSSION}

The worldwide ranking of OECD countries according to the Legatum Prosperity Index and the components of this index for 2019 is given in Table 2. As a result of the evaluation of this table, we can see the OECD countries where prosperity components are strong and weak.

Table 2. Ranking of OECD Countries by Legatum Prosperity Index Components (2019) (Equally Weighted)

\begin{tabular}{|c|c|c|c|c|c|c|c|c|c|c|c|c|c|}
\hline 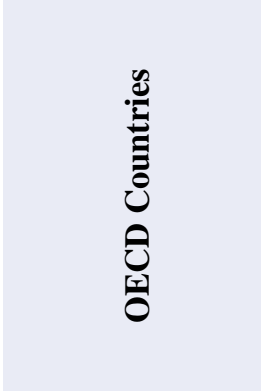 & 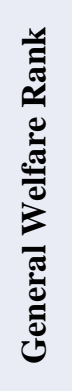 & 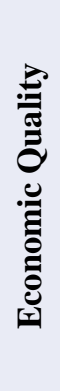 & 氖 & 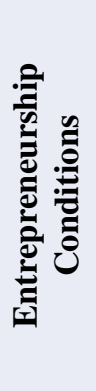 & 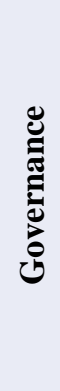 & 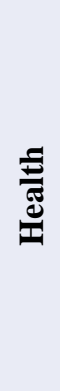 & 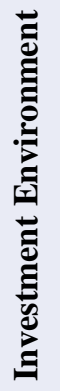 & 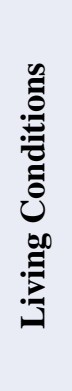 & 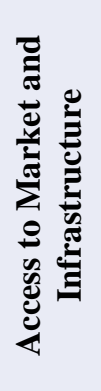 & 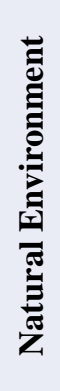 & 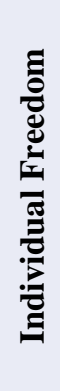 & 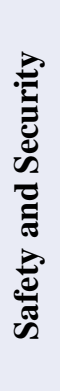 & 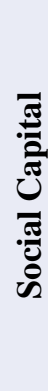 \\
\hline Norway & 2 & 12 & 11 & 9 & 1 & 5 & 2 & 7 & 15 & 7 & 1 & 2 & 1 \\
\hline Denmark & 1 & 8 & 3 & 7 & 3 & 8 & 6 & 1 & 8 & 10 & 2 & 5 & 2 \\
\hline Iceland & 10 & 16 & 13 & 30 & 13 & 7 & 25 & 20 & 12 & 8 & 6 & 6 & 3 \\
\hline Finland & 5 & 21 & 6 & 18 & 2 & 26 & 7 & 6 & 10 & 2 & 3 & 17 & 4 \\
\hline Netherlands & 6 & 6 & 8 & 8 & 4 & 9 & 12 & 2 & 4 & 54 & 5 & 12 & 6 \\
\hline New Zealand & 7 & 19 & 10 & 14 & 5 & 22 & 3 & 26 & 21 & 6 & 10 & 13 & 7 \\
\hline Switzerland & 3 & 2 & 12 & 3 & 7 & 3 & 13 & 4 & 7 & 5 & 12 & 1 & 8 \\
\hline Sweden & 4 & 4 & 17 & 13 & 6 & 15 & 10 & 3 & 5 & 1 & 4 & 11 & 9 \\
\hline Canada & 14 & 38 & 5 & 15 & 10 & 25 & 14 & 16 & 19 & 15 & 7 & 18 & 10 \\
\hline Austria & 13 & 22 & 22 & 19 & 15 & 10 & 11 & 13 & 17 & 3 & 17 & 9 & 11 \\
\hline Ireland & 12 & 3 & 16 & 10 & 14 & 20 & 23 & 12 & 23 & 14 & 9 & 14 & 12 \\
\hline Germany & 8 & 5 & 21 & 4 & 9 & 12 & 15 & 5 & 11 & 17 & 13 & 21 & 13 \\
\hline United Kingdom & 11 & 15 & 15 & 6 & 11 & 23 & 4 & 8 & 9 & 24 & 15 & 16 & 14 \\
\hline Australia & 17 & 31 & 9 & 21 & 12 & 18 & 9 & 21 & 29 & 19 & 14 & 26 & 15 \\
\hline USA & 18 & 17 & 14 & 2 & 21 & 59 & 8 & 29 & 6 & 25 & 22 & 58 & 16 \\
\hline
\end{tabular}




\begin{tabular}{|c|c|c|c|c|c|c|c|c|c|c|c|c|c|}
\hline Luxembourg & 9 & 7 & 33 & 16 & 8 & 19 & 22 & 9 & 2 & 9 & 8 & 3 & 21 \\
\hline Spain & 25 & 47 & 47 & 47 & 47 & 47 & 47 & 47 & 47 & 47 & 47 & 47 & 47 \\
\hline Estonia & 21 & 11 & 18 & 20 & 19 & 55 & 20 & 28 & 24 & 13 & 25 & 33 & 38 \\
\hline Slovenia & 27 & 24 & 40 & 33 & 32 & 41 & 23 & 26 & 4 & 27 & 23 & 40 & 24 \\
\hline France & 23 & 37 & 29 & 26 & 20 & 16 & 18 & 17 & 14 & 16 & 23 & 30 & 41 \\
\hline Belgium & 22 & 33 & 19 & 17 & 17 & 24 & 24 & 18 & 16 & 47 & 16 & 29 & 45 \\
\hline Portugal & 26 & 49 & 39 & 28 & 26 & 30 & 31 & 27 & 25 & 45 & 11 & 25 & 53 \\
\hline Italy & 30 & 52 & 31 & 25 & 39 & 17 & 40 & 24 & 32 & 48 & 29 & 24 & 56 \\
\hline Israel & 31 & 18 & 25 & 24 & 22 & 11 & 16 & 22 & 30 & 121 & 72 & 129 & 57 \\
\hline Chili & 37 & 51 & 46 & 39 & 28 & 70 & 37 & 44 & 34 & 55 & 28 & 66 & 65 \\
\hline Slovakia & 32 & 32 & 48 & 49 & 40 & 43 & 30 & 33 & 44 & 12 & 35 & 27 & 76 \\
\hline Hungary & 46 & 30 & 45 & 57 & 72 & 52 & 45 & 37 & 45 & 30 & 89 & 39 & 90 \\
\hline Colombia & 72 & 75 & 73 & 77 & 68 & 44 & 71 & 83 & 68 & 32 & 74 & 153 & 97 \\
\hline Poland & 36 & 39 & 34 & 32 & 38 & 40 & 38 & 31 & 42 & 62 & 62 & 22 & 111 \\
\hline Czechia & 28 & 13 & 26 & 35 & 31 & 28 & 26 & 32 & 35 & 18 & 32 & 20 & 112 \\
\hline Greece & 42 & 88 & 41 & 34 & 41 & 33 & 93 & 39 & 38 & 29 & 43 & 42 & 114 \\
\hline Mexico & 67 & 45 & 74 & 75 & 80 & 37 & 66 & 81 & 53 & 78 & 68 & 140 & 118 \\
\hline Latvia & 35 & 34 & 30 & 37 & 37 & 87 & 34 & 40 & 40 & 11 & 39 & 34 & 130 \\
\hline Japan & 19 & 26 & 7 & 11 & 18 & 2 & 17 & 19 & 13 & 23 & 31 & 10 & 132 \\
\hline Lithuania & 33 & 35 & 27 & 36 & 34 & 92 & 32 & 38 & 37 & 27 & 38 & 28 & 141 \\
\hline South Korea & 29 & 10 & 2 & 33 & 30 & 4 & 21 & 25 & 20 & 75 & 46 & 35 & 142 \\
\hline Turkey & 91 & 67 & 80 & 58 & 111 & 64 & 50 & 54 & 57 & 110 & 146 & 149 & 147 \\
\hline
\end{tabular}

Source: https://www.prosperity.com/ Accessed Date: 10.08.2020

Looking at Table 2, it is seen that the top 10 countries in OECD countries in terms of welfare in 2019 are Denmark, Norway, Switzerland, Sweden, Finland, the Netherlands, New Zealand, Germany, Luxembourg, and Iceland equally weighted. These countries have the same rankings not only among OECD countries but also in global scale. For this reason, it would not be wrong to think that the countries that are members of the OECD are composed of the countries with the highest welfare level in the world. Considering the welfare components of Denmark, which is placed first, it is seen that it is the best in the world in other components such as Living conditions, Personal Freedom, Social Capital, Education and Governance. This situation is similar for other countries that share the top 10 ranking. As development is not a concept that only carries an economic dimension, as we mentioned in our study, countries can create distinct differences in their welfare level by giving importance to other factors. For example, we see that Finland, which is the $5^{\text {th }}$ most prosperous country in the world in terms of general welfare level, is ranked $21^{\text {st }}$ in the world in terms of economic quality. However, Finland has managed to find itself among the top 10 countries with the highest welfare level, with its high ranking in the titles of education, governance, natural environment, personal freedoms, and social capital. In this context, it can be thought that countries have different strengths and weaknesses.

We can examine the change of social capital over the years for OECD countries by looking at the data in Table 3. In the Legatum index, the level of individual and social relations is assessed by "social capital" in each country. Corporate trust, social norms, and civic participation are also measured by the "social capital". In this respect, it is also necessary to know the concepts on which social capital is prepared. 
Table 3. Social Capital Ranking of OECD Countries by Legatum Welfare Index (2009-2019)

\begin{tabular}{|c|c|c|c|c|c|c|c|c|c|c|c|}
\hline $\begin{array}{c}\text { OECD } \\
\text { Countries }\end{array}$ & 2009 & 2010 & 2011 & 2012 & 2013 & 2014 & 2015 & 2016 & 2017 & 2018 & 2019 \\
\hline Norway & 3 & 2 & 3 & 2 & 1 & 2 & 1 & 1 & 2 & 1 & 1 \\
\hline Denmark & 1 & 1 & 1 & 1 & 2 & 1 & 3 & 2 & 1 & 2 & 2 \\
\hline Iceland & 8 & 10 & 10 & 11 & 12 & 8 & 8 & 10 & 9 & 6 & 3 \\
\hline Finland & 6 & 6 & 5 & 5 & 5 & 6 & 5 & 4 & 5 & 3 & 4 \\
\hline Netherlands & 2 & 5 & 7 & 8 & 8 & 9 & 4 & 7 & 4 & 5 & 6 \\
\hline New Zealand & 5 & 3 & 4 & 3 & 3 & 3 & 2 & 3 & 3 & 4 & 7 \\
\hline Switzerland & 4 & 8 & 9 & 9 & 6 & 5 & 9 & 8 & 10 & 7 & 8 \\
\hline Sweden & 7 & 4 & 2 & 4 & 4 & 4 & 6 & 5 & 6 & 8 & 9 \\
\hline Canada & 11 & 7 & 8 & 7 & 7 & 7 & 7 & 6 & 7 & 12 & 10 \\
\hline Austria & 9 & 13 & 13 & 14 & 13 & 12 & 16 & 17 & 17 & 18 & 11 \\
\hline Ireland & 13 & 12 & 11 & 10 & 11 & 11 & 11 & 13 & 12 & 13 & 12 \\
\hline Germany & 14 & 15 & 16 & 17 & 16 & 16 & 12 & 11 & 15 & 15 & 13 \\
\hline $\begin{array}{l}\text { United } \\
\text { Kingdom }\end{array}$ & 16 & 17 & 15 & 16 & 15 & 17 & 18 & 19 & 19 & 17 & 14 \\
\hline Australia & 10 & 9 & 6 & 6 & 10 & 10 & 10 & 9 & 8 & 11 & 15 \\
\hline U.S.A. & 12 & 11 & 12 & 12 & 9 & 13 & 15 & 15 & 16 & 14 & 16 \\
\hline Luxembourg & 17 & 18 & 17 & 19 & 21 & 66 & 24 & 26 & 26 & 19 & 21 \\
\hline Spain & 18 & 34 & 28 & 34 & 28 & 40 & 37 & 39 & 34 & 27 & 30 \\
\hline Estonia & 59 & 75 & 84 & 41 & 53 & 54 & 56 & 46 & 31 & 31 & 38 \\
\hline Slovenia & 20 & 31 & 20 & 31 & 31 & 43 & 40 & 40 & 36 & 28 & 40 \\
\hline France & 22 & 42 & 36 & 35 & 45 & 51 & 62 & 55 & 57 & 42 & 41 \\
\hline Belgium & 25 & 26 & 32 & 39 & 40 & 30 & 28 & 27 & 28 & 25 & 45 \\
\hline Portugal & 66 & 60 & 75 & 84 & 57 & 53 & 50 & 56 & 56 & 46 & 53 \\
\hline Italy & 50 & 27 & 54 & 50 & 29 & 56 & 58 & 62 & 59 & 49 & 56 \\
\hline İsrael & 71 & 62 & 78 & 61 & 62 & 58 & 83 & 50 & 46 & 37 & 57 \\
\hline Chili & 52 & 50 & 40 & 45 & 48 & 65 & 60 & 75 & 96 & 67 & 65 \\
\hline Slovakia & 121 & 119 & 110 & 97 & 106 & 111 & 103 & 111 & 85 & 60 & 76 \\
\hline Hungary & 84 & 79 & 99 & 79 & 79 & 63 & 109 & 119 & 95 & 79 & 90 \\
\hline Colombia & 46 & 55 & 51 & 48 & 36 & 62 & 75 & 79 & 86 & 87 & 97 \\
\hline Poland & 57 & 70 & 52 & 85 & 74 & 98 & 65 & 86 & 68 & 68 & 111 \\
\hline Czechia & 110 & 85 & 102 & 101 & 114 & 119 & 125 & 93 & 72 & 95 & 112 \\
\hline Greece & 97 & 104 & 122 & 125 & 133 & 140 & 108 & 90 & 112 & 134 & 114 \\
\hline Mexico & 101 & 82 & 80 & 104 & 96 & 112 & 121 & 148 & 120 & 127 & 118 \\
\hline Latvia & 89 & 115 & 121 & 89 & 97 & 83 & 88 & 94 & 106 & 115 & 130 \\
\hline Japan & 88 & 101 & 69 & 77 & 93 & 90 & 97 & 110 & 100 & 103 & 132 \\
\hline Lithuania & 161 & 164 & 164 & 158 & 158 & 159 & 159 & 149 & 154 & 102 & 141 \\
\hline South Korea & 134 & 127 & 98 & 118 & 121 & 123 & 145 & 143 & 131 & 121 & 142 \\
\hline Turkey & 163 & 162 & 161 & 163 & 164 & 160 & 85 & 100 & 82 & 131 & 147 \\
\hline
\end{tabular}

Source: https://www.prosperity.com/ Accessed Date: 10.08.2020

As seen in Table 3, the rankings of OECD countries according to the social capital variable differ from each other over the years. Countries in the top 10 for 2019 are Norway, Denmark, Iceland, Finland, the Netherlands, New Zealand, Switzerland, Sweden, and Canada. In countries with already high welfare levels, the level of social capital is also high. In the literature, it is stated that countries with high social capital are Scandinavian countries and that the ethnic homogeneity of these countries is also very effective in this regard (Glaeser,2004:18). The country located at the bottom of the list for 2019 OECD social capital ranking was Turkey. The reason for Turkey to be placed with such a low score among the OECD countries, is explained 
by its ethnic heterogeneity and the limiting impacts of low trust levels between individuals, according to surveys and the literature ${ }^{4}$.

In addition, it is seen in Table 3 that the social capital ranking of the countries has seriously deteriorated in some years. For example, in terms of social capital, Luxembourg ranked $21^{\text {st }}$ in 2013, but dropped to $66^{\text {th }}$ rank in 2014 and Turkey who was placed in $82^{\text {nd }}$ rank in 2017 dropped to $147^{\text {th }}$ rank in 2019. We can look at what kind of alteration these changes have caused in the welfare levels of countries in Table 4. As mentioned before, the 12 variables used in creating the Legatum welfare index are equally weighted. The ranking according to this equal weighting is given in Table 4 in the first column. The second column includes the ranking of countries when the social capital index is not considered as a welfare component, and the last column includes the situation where only the social capital index is considered a welfare component.

Table 4. Evaluation of the Welfare Ranking of OECD Countries in the Context of Social Capital Component According to Legatum Prosperity Index (2019)

\begin{tabular}{|c|c|c|c|}
\hline $\begin{array}{l}\text { OECD } \\
\text { Countries } \\
\text { Welfare } \\
\text { Ranking }\end{array}$ & $\begin{array}{l}\text { When Index Factors } \\
\text { Are Equally Weighted }\end{array}$ & $\begin{array}{c}\text { When Social } \\
\text { Capital Index Is } \\
\text { Subtracted from } \\
\text { Index Factors }\end{array}$ & $\begin{array}{l}\text { When Only Social } \\
\text { Capital Index } \\
\text { Considered Among } \\
\text { Index Factors }\end{array}$ \\
\hline Norway & 2 & 3 & 1 \\
\hline Denmark & 1 & 2 & 2 \\
\hline Iceland & 10 & 14 & 3 \\
\hline Finland & 5 & 5 & 4 \\
\hline Netherlands & 6 & 6 & 6 \\
\hline New Zealand & 7 & 10 & 7 \\
\hline Switzerland & 3 & 1 & 8 \\
\hline Sweden & 4 & 4 & 9 \\
\hline Canada & 14 & 15 & 10 \\
\hline Austria & 13 & 13 & 11 \\
\hline Ireland & 12 & 12 & 12 \\
\hline Germany & 8 & 8 & 13 \\
\hline $\begin{array}{l}\text { United } \\
\text { Kingdom }\end{array}$ & 11 & 9 & 14 \\
\hline Australia & 17 & 18 & 15 \\
\hline U.S.A. & 18 & 19 & 16 \\
\hline Luxembourg & 9 & 7 & 21 \\
\hline Spain & 25 & 25 & 30 \\
\hline Estonia & 21 & 21 & 38 \\
\hline Slovenia & 27 & 29 & 40 \\
\hline France & 23 & 22 & 41 \\
\hline Belgium & 22 & 20 & 45 \\
\hline Portugal & 26 & 28 & 53 \\
\hline Italy & 30 & 30 & 56 \\
\hline İsrael & 31 & 32 & 57 \\
\hline Chili & 37 & 37 & 65 \\
\hline Slovakia & 32 & 34 & 76 \\
\hline Hungary & 46 & 43 & 90 \\
\hline Colombia & 72 & 72 & 97 \\
\hline Poland & 36 & 36 & 111 \\
\hline
\end{tabular}

\footnotetext{
${ }^{4}$ https://www.oecd-ilibrary.org/docserver/9789264189515- 


\begin{tabular}{|l|l|l|l|}
\hline Czechia & 28 & 26 & 112 \\
\hline Greece & 42 & 40 & 114 \\
\hline Mexico & 67 & 62 & 118 \\
\hline Latvia & 35 & 33 & 130 \\
\hline Japan & 19 & 17 & 132 \\
\hline Lithuania & 33 & 31 & 141 \\
\hline South Korea & 29 & 27 & 142 \\
\hline Turkey & 91 & 85 & 147 \\
\hline
\end{tabular}

Source: https://www.prosperity.com/ Accessed Date: 10.08.2020

It can be seen in Table 4 that when social capital is removed from the index components in Denmark, which ranks first in the welfare ranking, Denmark falls to the $2^{\text {nd }}$ rank in the welfare level. Switzerland rises to the first place. It can be said that the social capital component of Switzerland has a lower score than other components, and when it is removed for this reason, the welfare level of the country increases significantly and moves to the first place. As a matter of fact, it is seen that Switzerland is in the $8^{\text {th }}$ place in the social capital ranking. Among the OECD countries, the country in which social capital is in a dramatically bad condition is Japan. As of 2019, Japan ranks $132^{\text {nd }}$ in the social capital ranking. However, it ranks $19^{\text {th }}$ in the general welfare ranking and $17^{\text {th }}$ when social capital is removed. This suggests that Japan has a very good score in the other 11 variables used in welfare evaluations other than social capital. Therefore, it would be meaningful to bring together countries that are strong in terms of social capital component and where this power has an improving effect on the general welfare ranking, and OECD countries whose social capital component is weak and where this weakness has a worsening effect on the general welfare level. This grouping is included in Table 5. While doing this grouping, Table 4 was used, and the ranking was compared when the social capital index was subtracted from the index factors and the index factors were equally weighted. As a result of this comparison, if there is a deterioration in the ranking of the country when the social capital index is removed, it is believed that social capital has an improving effect on the general welfare level in this country; if there is an improvement in the ranking of the country when the social capital index is removed, it is believed that social capital in this country has a worsening effect on the general welfare level. If no change in ranking is observed, it is accepted that social capital has no effect on welfare.

Table 5: Evaluation of the Changes in Welfare Levels of Countries in Terms of the Effect of Social Capital (2019)

\begin{tabular}{|l|l|l|}
\hline $\begin{array}{l}\text { Countries Where Social Capital } \\
\text { Has a Healing Effect in General } \\
\text { Welfare Level Ranking }\end{array}$ & $\begin{array}{l}\text { Countries Where Social Capital } \\
\text { Has A Deteriorating Effect in The } \\
\text { Ranking of the General Welfare } \\
\text { Level }\end{array}$ & $\begin{array}{l}\text { Countries Where Social } \\
\text { Capital Does Not Have an } \\
\text { Impact on General Welfare }\end{array}$ \\
\hline Norway & Switzerland & Finland \\
\hline Denmark & United Kingdom & Netherlands \\
\hline Iceland & Luxembourg & Sweden \\
\hline New Zealand & France & Austria \\
\hline Canada & Belgium & Ireland \\
\hline Australia & Hungary & Germany \\
\hline U.S. A & Czechia & Spain \\
\hline Slovenia & Greece & Estonia \\
\hline Portugal & Mexico & Italy \\
\hline Israel & Latvia & Chili \\
\hline Slovakia & Japan & Colombia \\
\hline & Lithuania & Poland \\
\hline
\end{tabular}




\begin{tabular}{|l|l|l|}
\hline & South Korea & \\
\hline & Turkey & \\
\hline & & \\
\hline
\end{tabular}

Created by Authors

When Table 5 is examined, it is seen that while it is possible to say that social capital has an improving effect on the general welfare level in some countries, in some countries this effect is in a worsening direction and in some countries, it has no effect. This situation can be interpreted as follows. In countries that are already weak in terms of social capital, social capital reduces welfare to a lower level than it should be. As an example, we can name Hungary, Czechia, Greece, Mexico, Latvia, Japan, Lithuania, South Korea, and Turkey. When the social capital rankings of these countries are examined, it is seen that they already have $90^{\text {th }}$ and above rankings worldwide. In this context, it would be appropriate to consider that countries with this bad record in social capital suffer from the reducing effect created by social capital on their general welfare level. However, there is another interesting point here, which is that these countries have high social capital scores, but their social capital reduces their welfare level. These countries are Switzerland, United Kingdom, Luxembourg, France, and Belgium. Social capital rankings of these countries are $8^{\text {th }}, 14^{\text {th }}, 21^{\text {st }}, 41^{\text {st }}$ and $45^{\text {th }}$ respectively. Despite their high scores in world-wide ranking, the presence of social capital in these countries has caused them to fall behind in the rank of wealth. This recalls us the existence of the 'dark side' of social capital in these countries.

The lack of an agreed definition and dimensions of the concept of social capital prevented indeed the realization that the concept may have different aspects. Therefore, although social capital is seen as a concept that always produces positive outputs in mainstream literature, studies have shown that social capital can also have outputs that negatively affect countries' welfare levels. The best example of this is the acquisition of the view and supporting data, which was later expressed as the "dark side of social capital", indicating that communication and relationship networks will not only yield positive results (Field, 2008:101). It has been mentioned that the relationships and networks used in defining social capital can also be used for malicious purposes and for example, various criminal organizations can be explained by this. Social capital theorists have included these researches and data in the literature as "the dark side of social capital" (Narayan, 1999).

\section{CONCLUSION}

Our study has shown that social capital is an important input in the difference between welfare levels of countries. Another question that needs to be answered here is where the countries stand in terms of only social capital component. The answer to this question is crucial for understanding the severity and extent of the impact social capital has on general welfare. It has been seen that social capital is also high in countries with high levels of welfare across OECD countries. However, there are exceptions to this. OECD countries with a high general welfare level but relatively low social capital level are Japan, Poland, Czechia, Greece, Lithuania, and South Korea. While these countries are among the top 40 countries in the world in terms of general welfare level, they rank $100^{\text {th }}$ and above in the world in terms of social capital. In this context, it has been seen in the literature that although "social capital feeds high welfare level" hypothesis existing in the literature may be valid, it cannot be deduced that "high welfare level feeds social capital". In this context, it is not correct to mention a bi-directional linear correlation relationship between the concepts of welfare and social capital in all OECD countries.

The comparison of the results obtained by adding and subtracting social capital to the Legatum Prosperity Index calculation showed that while it is possible to say that the countries at 
the top of the social capital rankings have an improving effect on the general welfare level of social capital in some countries, this effect is worsening in some countries, and there is no effect in some countries.

Therefore, it can be said that in countries that are already behind the ranking on social capital, social capital reduces the welfare level to a lower level than it should be. As an example, we can cite Hungary, Czechia, Greece, Mexico, Latvia, Japan, Lithuania, South Korea and Turkey. When the social capital rankings of these countries are examined, it is seen that they already have $90^{\text {th }}$ and above rankings worldwide.

In this context, it would be appropriate to consider that the relatively low general welfare levels of countries with bad ratings in terms of social capital stem from the reducing effect created by social capital. However, another interesting point here is that countries with high social capital scores had seen their welfare levels reduced by the presence of social capital. These countries are Switzerland, United Kingdom, Luxembourg, France, and Belgium. Social capital rankings of these countries are $8^{\text {th }}, 14^{\text {th }}, 21^{\text {st }}, 41^{\text {st }}$ and $45^{\text {th }}$. Despite the high scores in this world-wide ranking, the presence of social capital in these countries has caused them to fall behind in wealth ranking. This reminds us the existence of the 'dark side of social capital' in these countries. The situation defined as the 'dark side of social capital' is the existence of negativities such as nepotism and favouritism of various network groups. Thus, the output of social capital may not be positive. Social capital may also have a negative impact in some countries.

\section{References}

Bourdieu, Pierre (1986), “The Forms of Capital”, Ed.J.J. Richardson, Handbook of Theory and Research for Sociology of Education, Greenwood Press, New York.

Coleman, James (1998), "Social Capital in the Creation of Human Capital". The American Journal of Sociology, 94, p.95-120.

Dzialek, Jaroslaw (2014), "Is Social Capital Useful For Explaining Economic Development In Polish Regions?", Geografiska Annaler; Series B, Human Geography, 96 (2), p.177-193.

Field, James (2008), “Sosyal Sermaye”, (Çev.) Bahar Bilgen ve Bayram Şen, İstanbul: İstanbul Bilgi Üniversitesi Yayınları.

Fukuyama, Francis (1995), “Trust: The Social Virtues and The Creation Of Prosperity”. New York: Free Press.

Glaeser, Edward L. (2004), "The Formation of Social Capital". NBER Working Paper. http://www.oecd.org/innovation/research/1824983.pdf

Karagül, Mehmet and Akçay, Selçuk (2002), "Ekonomik Büyüme ve Sosyal Sermaye: Ampirik Bir Kanıt”, İktisat, İsletme ve Finans, Eylül, p. 82-99.

Knack, Stephan and Keefer, Philip (1997), "Does Social Capital Have an Economic Payoff? A Cross Country Investigation", The Quarterly Journal of Economics, 112(4), p. 12511288.

Khan, Abdul Jalil and Ahmad, Hafiz Rizwan. (2019), "Prosperity and Instability: An Evaluation of Legatum Prosperity Index", Papers and Proceedings, p. 407-431. https://www.pide.org.pk/psde/pdf/AGM33/papers/Abdul\%20Jalil\%20Khan.pdf

Legatum Prosperity Index Report, https://www.prosperity.com/about/resources 
Legatum Prosperity Index, https://docs.prosperity.com/3916/0568/0669/The_Legatum_Prosperity_Index_2020_Over view.pdf Accessed Date: 20.10.2020

Narayan, Deepa. (1999), "Bonds and Bridges". World Bank Policy Research Working Paper. Washington, DC: World Bank.

Putnam, Robert. (1994), “Making Democracy Work: Civic Tradition's In Modern Italy", Princeton University Press, New Jersey.

Rupasingha, Anil and Goetz, Stephan J. and Freshwater, David (2000), "Social Capital and Economic Growth: A County-Level Analysis", Journal of Agricultural and Applied Economics, 32 (3), p.565-572.

Sabbatini, Fabio. (2005). "The Role of Social Capital in Economic Development: Investigating the Causal Nexus Through Structural Equations Models", https://ssrn.com/abstract=901361 or http://dx.doi.org/10.2139/ssrn.901361, p.1-27.

Soumyananda, Dinda. (2012). "Social Capital Formation Ensuring Inclusive Growth: A Development Mechanics for Backward Region", MPRA, Paper no: 66261, https://mpra.ub.uni-muenchen.de/66261/

Şan, Mustafa Kemal and Şimşek, Rıdvan (2011), "Sosyal Sermaye Kavramının TarihselSosyolojik Arkaplanı”, Akademik Incelemeler Dergisi, 6 (1), p. 88-110.

Palomino Peiro, Jesus. (2016), "Social Capital and Economic Growth in Europe: Nonlinear Trends and Heterogeneous Regional Effects, Oxford Bulletin of Economics and Statistics, 78 (5), p.717-751.

Torsvik, Gaute. (2000), "Social Capital and Economics Development: A Plea fort he Mechanism”, Rationality and Society, 12 (4), p.451-476.

Whiteley, Paul F.(2000), "Economic Growth and Social Capital”, Political Studies, Vol.48, p. 443-466.

Woolcock, Michael. (1998), "Social Capital and Economic Development: Toward A Theoretical Synthesis and Policy Framework", Theory and Society, 27, p.151-208. 